NASA Technical Memorandum 107153

\title{
Hot Hydrogen Exposure Degradation of the Strength of Mullite
}

Thomas P. Herbell, David R. Hull, and Anita Garg

Lewis Research Center

Cleveland, Ohio

June 1996

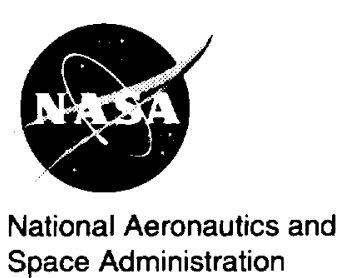




\title{
HOT HYDROGEN EXPOSURE DEGRADATION OF THE STRENGTH OF MULLITE
}

\author{
Thomas P. Herbell, David R. Hull,* and Anita Garg \\ National Aeronautics and Space Administration \\ Lewis Research Center \\ Cleveland, Ohio 44135
}

\begin{abstract}
This study deals with the corrosion of near stoichiometric mullite $\left(3 \mathrm{Al}_{2} \mathrm{O}_{3}-2 \mathrm{SiO}_{2}\right)$ by pure dry hydrogen gas. Exposure of the mullite samples was at temperatures of 1050 and $1250^{\circ} \mathrm{C}$ for times up to $500 \mathrm{hr}$. Preferential attack of the aluminosilicate glass present in the grain boundaries of the mullite occurred after $125 \mathrm{hr}$ at $1250^{\circ} \mathrm{C}$. Hydrogen scrubbing of the $\mathrm{SiO}_{2}$ from the glassy grain boundaries and the mullite grains yielded a porous aluminarich surface. The room temperature strength increased after short exposure times at $1250^{\circ} \mathrm{C}$ (up to $125 \mathrm{hr}$ ), then decreased by 53 percent after exposure for $500 \mathrm{hr}$. At $1050^{\circ} \mathrm{C}$, all exposure times ( 25 to $500 \mathrm{hr}$ ) decreased the strength. After $500 \mathrm{hr}$ in hydrogen at $1050^{\circ} \mathrm{C}$, the room temperature strength of mullite decreased 22 percent. We also observed a rapid 25 percent strength loss after short exposure times at $1050^{\circ} \mathrm{C}$. This is attributed to the calcium/hydrogen assisted crystallization of the glassy, grain-boundary phase.
\end{abstract}

\section{INTRODUCTION}

Strength retention to high temperature combined with low thermal expansion make the monolithic form of mullite $\left(3 \mathrm{Al}_{2} \mathrm{O}_{3}-2 \mathrm{SiO}_{2}\right)$ a potentially useful material for many structural applications. At the time this study was initiated it was a candidate for the pressure vessel in the hot zone of a ceramic Stirling engine. Current technical needs emphasize the use of mullite as a matrix and/or as a reinforcing fiber for advanced fiber reinforced ceramic matrix composites. Mullite coatings are also being developed to enhance the environmental durability of the siliconbased ceramics, $\mathrm{SiC}$ and $\mathrm{Si}_{3} \mathrm{~N}_{4}$. In some applications, the operating conditions will be highly reducing and may require significant strength retention, even after long time exposure to hydrogen at elevated temperature. Examples include the ceramic Stirling engine mentioned above and future hydrogen-fueled hypersonic vehicles. Operating temperatures in a Stirling pressure vessel could approach $1200^{\circ} \mathrm{C}$. Applications for hypersonic vehicles may require

\footnotetext{
"National Research Council-NASA Research Associate at Lewis Research Center.
} 
even higher hydrogen exposure temperatures. Under these conditions, corrosion of the mullite may occur because of uniform material loss, and/or selective pitting, which decrease the fracture strength.

The effect of high temperature hydrogen exposure on the microstructure of mullite, along with the kinetics of the reaction, has been the subject of several investigations. Wright and Wolf (Ref. 1) found that severe chemical attack of refractory mullite occurs when exposed to hydrogen above $1370^{\circ} \mathrm{C}$. Crowley ( Ref. 2) further studied the effects of hydrogen on refractory mullite and measured the rate of silica loss at $1425{ }^{\circ} \mathrm{C}$. He concluded that the weight loss was dependent on the hydrogen flow rate and that the hydrogen-mullite reaction was diffusion controlled. He also observed a decrease in compressive strength with increasing weight loss. Chen (Ref. 3), using techniques similar to those of Crowley, found the reaction of mullite with hydrogen to be a mixed control process. He said that the reaction depended on the transportation of the gaseous product species through the porous product layer and through the gaseous boundary layer. The amount of weight loss was also dependent on the flow rate of hydrogen over the mullite. The reduction of mullite by hydrogen gas was studied in more detail by Tso and Pask (Ref. 4). These investigators used a high purity stoichiometric mullite in their tests. Later, Tso (Ref. 5) found that diffusion through the porous layer was not rate limiting, but the reduction reaction was. All of the above investigators identified the loss of silica from the mullite to be the major reaction. The result of this reaction is a porous product layer of alpha alumina on the surface.

$$
\mathrm{Al}_{6} \mathrm{Si}_{2} \mathrm{O}_{13}(\mathrm{~s})+2 \mathrm{H}_{2}(\mathrm{~g}) \rightarrow 3 \mathrm{Al}_{2} \mathrm{O}_{3}(\mathrm{~s})+2 \mathrm{SiO}(\mathrm{g})+2 \mathrm{H}_{2} \mathrm{O}(\mathrm{g})
$$

A review of the literature reveals that the hydrogen mullite reaction has only been studied at temperatures above $1350{ }^{\circ} \mathrm{C}$ and mainly for short times, i.e., a maximum of $50 \mathrm{hr}$. In applications such as the Stirling engine several thousand $\mathrm{hr}$ of exposure at somewhat lower temperatures is required.

The objective of this study was to determine the effect of long time hydrogen exposure on the microstructure and retained room temperature strength of near stoichiometric mullite. 


\section{EXPERIMENTAL}

Mullit' test bars 6 by 3 by $25 \mathrm{~mm}$ were prepared by diamond grinding. The bars were ultrasonically cleaned in neat ethanol, dried, measured and weighed before each hydrogen exposure. Approximately 20 test bars were used in each hydrogen test.

The hydrogen gas was dried and purified to a moisture level of about $1 \mathrm{ppm}$. The flow rate was regulated at room temperature and held constant at $475 \mathrm{cc} / \mathrm{min}$. Hydrogen exposures were done in a silicon carbide resistance heated horizontal tube furnace with a 99.8 percent pure $\mathrm{Al}_{2} \mathrm{O}_{3}$ tube. The specimens were placed on high purity $\mathrm{Al}_{2} \mathrm{O}_{3}$ setters in a high purity $\mathrm{Al}_{2} \mathrm{O}_{3}$ boat located in the central hot-zone of the furnace. The temperature variation within the furnace hot-zone was about $\pm 10^{\circ} \mathrm{C}$.

Heating to the exposure temperature was in high purity helium. Once the desired temperature was achieved, the atmosphere was switched to hydrogen. At the completion of the exposure cycle, the gas was again switched to helium for the cool-down cycle. The mullite samples were exposed to hydrogen at 1050 and $1250{ }^{\circ} \mathrm{C}$ for times of 25 to $500 \mathrm{hr}$.

At the completion of the hydrogen exposure, the samples were removed from the furnace, weighed, and measured. The exposed specimens were subsequently stressed to fracture in a four-point bend fixture. The loading rate was $0.05 \mathrm{~cm} / \mathrm{min}$ with an outer span of $1.90 \mathrm{~cm}$ and an inner span of $0.95 \mathrm{~cm}$. The following equation:

$$
\text { MOR Strength }=3 \mathrm{P}(\mathrm{L}-\mathrm{a}) / 2 \mathrm{bd}^{2}
$$

was used to calculate fracture strength.; $P$ is the load at failure, $L$ is the outer span, $a$ is the inner span, $b$ is the specimen width, and $d$ is the specimen thickness. The original sample dimensions were used to calculate the fracture stresses. Results showed that the surface recession due to material loss on the surface did not exceed $20 \mu \mathrm{m}$ and was considered to have no significant effect ( $<2$ percent) on the strength calculation.

'K-635 mullite, Kyocera International, San Diego, CA. 
A number of techniques were used to characterize the exposed samples including: $\mathrm{X}$-ray diffraction (XRD), scanning electron microscopy (SEM), X-ray energy dispersive spectroscopy (XEDS), transmission electron microscopy (TEM), selected area diffraction (SAD), electron microprobe, and optical microscopy.

\section{RESULTS AND DISCUSSION}

Etching the as-received mullite with a 2:1 mixture of $\mathrm{HCl} / \mathrm{HF}: \mathrm{H}_{2} \mathrm{O}$ for five seconds revealed the microstructure shown in Fig. 1. In the as-received sample, the grains were highly acicular with an aspect ratio approaching 8 and an average grain length of $10 \mu \mathrm{m}$. A silica-rich glass (marked G in Fig. 1) between the mullite grains (marked M in Fig. 1) makes up about 16 percent of the structure. This is typical of commercial mullites. The slow transport rates of the constituent species require the use of excess silica to facilitate densification. As shown in Table I, this mullite also contained calcium and magnesium for enhancement of sintering.

Table I.-Chemical Analysis of Mullite, wt $\%$

$\begin{array}{ccccc}\text { Aluminum } & \text { Silicon } & \text { Calcium } & \text { Iron } & \text { Magnesium } \\ 35.4 & 13.8 & 0.7 & 0.3 & 0.8\end{array}$

Elements not detected (<1ppm): B, Ba, Co, Cr, Mn, Mo, Ni, P, Ti, V, Y, Zn, Zr.

Point count approximation on ceramographic sections indicated a porosity of about 3 percent. This value was confirmed by immersion density measurements. The measured bulk density was $3.05 \pm 0.01 \mathrm{~g} / \mathrm{cc}$.

Hydrogen corrosion is seen in the photomicrographs of Fig. 2. This figure shows the as- ground surface of the mullite in the as-received condition and after $500 \mathrm{hr}$ exposure in hydrogen at 1050 and $1250^{\circ} \mathrm{C}$. Large surface voids were present in the as received material, but the surface between voids was quite dense (Fig. 2(a)). The initial effects of surface corrosion are seen as material loss across the surface after $500 \mathrm{hr}$ at $1050^{\circ} \mathrm{C}$ (Fig. 2(b)). The grain-boundary glass phase is the first material removed from the surface, revealing clearly mullite's needle like structure. Surface corrosion at $1250^{\circ} \mathrm{C}$ is more severe. After $500 \mathrm{hr}$ (Fig. 2(c)) the glass is no longer evident and actual corrosion of the mullite grains is seen. 
Corrosion of the mullite was so severe at $1250^{\circ} \mathrm{C}$ that formation of silica whiskers was frequently observed near the outlet end of the furnace tube. The formation of gaseous $\mathrm{SiO}$ and $\mathrm{H}_{2} \mathrm{O}$ occurs when $\mathrm{SiO}_{2}$ reacts with hydrogen according to the following equation:

$$
\mathrm{Si}_{2}(\mathrm{~s})+\mathrm{H}_{2}(\mathrm{~g}) \rightarrow \mathrm{SiO}(\mathrm{g})+\mathrm{H}_{2} \mathrm{O}(\mathrm{g})
$$

It is assumed this same reaction is occurring to the aluminosilicate glass located in the grain boundaries. Corrosion of the mullite grains seen at $1250{ }^{\circ} \mathrm{C}$ can also contribute to the formation of SiO by the reaction shown in Eq. 1. The SiO from these reactions is removed from the reaction layer by the bulk gas and transported to the cooler outlet end of the furnace tube where conditions are favorable for reoxidation to $\mathrm{SiO}_{2}$. Removal of $\mathrm{SiO}_{2}$ from the glass phase and the mullite grains leaves regions of porous alpha alumina behind. The resulting alumina-rich surface was analyzed by XEDS, and Fig. 3 shows the increase in aluminum/silicon XEDS peak height ratio in going from the as-received material to the exposed material after 125 and $500 \mathrm{hr}$ at $1250^{\circ} \mathrm{C}$.

Removal of the $\mathrm{SiO}_{2}$ also contributes to a drop in density and an increase in porosity near the surface. Figure 4 shows the effect of exposure time on the density of samples heated in hydrogen at $1250^{\circ} \mathrm{C}$. The density decrease seems linear with time up to the maximum of $500 \mathrm{hr}$ studied. The porous surface layer formed by hydrogen corrosion is shown in the back-scattered electron SEM micrographs of Fig. 5.2 Figure 5 (a) is a cross-section of an as-received mullite specimen with the top surface marked $X$. Several large voids (10 to $15 \mu \mathrm{m}$ in diameter) visible in this micrograph, were also present in all the exposed samples (Figs. 5 (b to d)). During exposure to $\mathrm{H}_{2}$, escape of $\mathrm{SiO}$ (g) produced by reaction (Ref. 3 ) leaves porous regions in the material. The extent of the porosity depends on both the time and temperature of the exposure. At $1050^{\circ} \mathrm{C}$, exposure for $500 \mathrm{hr}$ produces a porous layer only about $4 \mu \mathrm{m}$ deep marked by $\mathrm{Y}$ in Fig. 5 (b). At $1250^{\circ} \mathrm{C}$, exposures of 125 and $500 \mathrm{hr}$ produce porous surface layers. The layer is $150 \mu \mathrm{m}$ deep after $125 \mathrm{hr}$ and increases to a depth of $375 \mu \mathrm{m}$ after $500 \mathrm{hr}$. Chen (Ref. 3) found the reaction rate to depend on the position of the bars in the furnace and the flow rate of the hydrogen. This implies that removal

\footnotetext{
${ }^{2}$ Backscattered electron (BSE) imaging is used to image glass removal. During mounting for ceramographic preparation, epoxy infiltrates the sample, filling pores where the glass was removed, In BSE imaging, contrast is provided by atomic number differences. The epoxy is composed of carbon, atomic number 6 , and the mullite has an average atomic number of 9.85 . Therefore, the epoxy filled voids show up darker than the mullite.
} 
of reaction products from the boundary layer, not transport through the porous reaction layer, is the rate controlling step in the corrosion process.

Fracture strength data for mullite bars exposed to hydrogen at 1050 and $1250{ }^{\circ} \mathrm{C}$ are shown in Fig. 6. Data for short time exposures in helium is also presented in the same figure. At room temperature, the fracture strength of as received mullite bars was approximately $211 \mathrm{MPa}$. All $1050^{\circ} \mathrm{C}$ exposures produced a significant strength loss. Most of this strength loss occurred in the first 25 to $50 \mathrm{hr}$, and was independent of exposure atmosphere, $\mathrm{H}_{2}$ or He. After $500 \mathrm{hr}$ in hydrogen the measured strength loss averaged 22 percent. The slight strength recovery, from $\approx 150 \mathrm{MPa}$ to $\approx 167 \mathrm{MPa}$, observed between 125 and $500 \mathrm{hr}$ exposure time is not believed to be of great significance. The loss in strength after $500 \mathrm{hr}$ of exposure is attributed primarily to formation of a thin porous reaction layer due to corrosion of the grain-boundary phase between the mullite grains. Because of the different strength behavior of bars exposed at $1250^{\circ} \mathrm{C}$, to be described later in this report, an attempt was made to rationalize the sudden loss in strength for short exposure times at $1050{ }^{\circ} \mathrm{C}$ in both hydrogen and helium through microstructural characterization.

Transmission electron microscopy revealed the presence of a faulted crystalline grain-boundary phase in samples exposed at $1050^{\circ} \mathrm{C}$ for $500 \mathrm{hr}$ (Figs. 7 (a) and (b)). This phase is present after both helium and hydrogen exposures. Strength reductions of 22-28 percent were observed when the crystalline grain-boundary phase was present regardless of surface corrosion. Dilatometric analyses indicate that the formation of the crystalline phase does not alter the thermal expansion behavior. Differential thermal analysis traces in air and helium were featureless. In contrast to $1050^{\circ} \mathrm{C}$, samples heated to $1250^{\circ} \mathrm{C}$, even for $500 \mathrm{hr}$, contain no crystalline grain-boundary phase (Figs. 7 (c) and (d)). Figs. 8 (a) and (b) shows the corresponding XEDS for the grain-boundary and the superimposed mullite phase in K-635 mullite for each temperature. Comparison of Figs. 8 (a) and (b) suggests that the crystalline grain-boundary phase in the 500 hour $/ 1050^{\circ} \mathrm{C}$ sample was rich in calcium and also contains some sodium in addition to aluminum and silicon. To identify this grain-boundary phase, selected area diffraction (SAD) patterns were recorded from several crystalline grains in different orientations. In each case, the SAD pattern could be unambiguously indexed to a calcium aluminosilicate hydride called beidellite, $\left[\left(\mathrm{Ca}, \mathrm{Na}_{2} \mathrm{Al}_{2} \mathrm{Si}_{4} \mathrm{O}_{10}(\mathrm{OH})_{2}\right]\right.$. $\mathrm{H}_{2} \mathrm{O}(6)$. Beidellite has an orthorhombic crystal structure with unit cell parameters: $a=0.518 \mathrm{~nm}, b=0.897 \mathrm{~nm}$, and $c=1.76$ $\mathrm{nm}$. The representative SAD patterns along zone axes [121], [421], and [210] are shown in Figs. 9 (a) to (c) 
respectively. Beidellite is a clay mineral which belongs to the montmorillonite group and is capable of absorbing water molecules between its sheet structure (Ref. 7).

Many high density ceramic compositions contain a glassy grain-boundary phase which, when exposed to high temperatures, can devitrify to a variety of crystalline phases. In sintered alumina materials it has been found that calcium facilitates the crystallization of the glassy grain-boundary phase (Ref. 8). It was therefore logical to see if calcium was the cause of the strength reducing recrystallized grain-boundary glass observed in the sample noted above. A sample of another high density mullite material, designated mullite- 1,3 which contained no detectable amounts of calcium was exposed to dry hydrogen for $50 \mathrm{hr}$ at $1050^{\circ} \mathrm{C}$. TEM of this sample, Figure 10 , reveals only amorphous grain-boundaries. Figure 11 shows the XEDS of such a grain-boundary. No calcium is detected. This observation led us to conclude that as with alumina, calcium plays a significant role in the recrystallization of the grain-boundary glass phase at $1050^{\circ} \mathrm{C}$. The presence of this recrystallized grain-boundary phase seems detrimental to the high temperature strength of mullite.

A different strength behavior was observed for samples exposed at $1250^{\circ} \mathrm{C}$. Short time exposure $(\leq 50 \mathrm{hr})$ to both hydrogen and helium resulted in a sharp strength increase of about 38 percent. For times $>50 \mathrm{hr}$, strength of mullite dropped continuously, but bars exposed to hydrogen for $125 \mathrm{hr}$ were still stronger than the baseline material. The increase in strength at short exposure times is suspected to be related to crack healing promoted by the flow of silicate glass on the surface and needs further study. Strength degradation after $500 \mathrm{hr}$ at $1250^{\circ} \mathrm{C}$ was approximately 53 percent. Crystallization of the glassy, grain-boundary phase that led to the strength degradation at $1050{ }^{\circ} \mathrm{C}$ was not observed. The strength loss after exposure at $1250^{\circ} \mathrm{C}$ is attributed to severe corrosion and actual removal of the glassy grain boundaries as shown in Fig. 5 .

\section{SUMMARY}

Near stoichiometric mullite was exposed to pure hydrogen at 1050 and $1250^{\circ} \mathrm{C}$ for times up to $500 \mathrm{hr}$.

1. Exposure to hydrogen for $500 \mathrm{hr}$ at $1050^{\circ} \mathrm{C}$ reduced room temperature strength by 22 percent. At $1250^{\circ} \mathrm{C}$ the corresponding loss was 53 percent.

\footnotetext{
${ }^{3}$ Ispsen Ceramics, Pecatonica, IL.
} 
2. Strength loss after long exposure times is related to the removal of $\mathrm{SiO}_{2}$ from the grain boundaries (and from the mullite grains at $1250^{\circ} \mathrm{C}$ ).

3. Strength loss after short exposures at $1050{ }^{\circ} \mathrm{C}$ is due to the formation of a crystalline grain-boundary phase, beidellite.

4. In hydrogenous atmospheres, the presence of calcium promotes the crystallization of the grain-boundary phase, bediellite at $1050^{\circ} \mathrm{C}$.

5. Strength enhancement after short exposures at $1250^{\circ} \mathrm{C}$ is suspected to be due to healing of surface flaws due to flow of the silicate glass phase on the surface.

\section{CONCLUSIONS}

Room temperature fracture strength of the mullite used in this study is severely degraded by long time exposure to hydrogen at 1050 and $1250^{\circ} \mathrm{C}$. Corrosion of the grain boundaries occurs at both temperatures and at $1250^{\circ} \mathrm{C}$, even the mullite grains are slightly attacked. The presence of calcium promotes the intermediate temperature $\left(1050^{\circ} \mathrm{C}\right.$ in this case) recrystallization of the glassy, grain-boundary phase which degrades the strength of mullite even at short exposure times. These results indicate that the calcium content of mullite intended for use at temperatures ca $1050{ }^{\circ} \mathrm{C}$ should be as low as possible. Pure mullite without the presence of a secondary glass phase may be suitable for use in hydrogen below $1250^{\circ} \mathrm{C}$. Production of mullite without a glass phase is, however, extremely difficult.

\section{REFERENCES}

1. R. E. Wright and H. I. Wolf, "Refractory Problems in Production of Hydrogen by Pyrolysis of Natural Gas", J. Am. Cer. Soc., 31 [2] 31-38 (1948)

2. M.S. Crowley,'Hydrogen-Silica Reactions in Refractories", Bull Am. Cer. Soc., 46 [7] 679-682 (1967)

3. C. I. Chen, "The Reduction of Silica and Mullite in Hydrogen", Ph.D. Thesis, Ohio State University, (1979)

4. S. T. Tso and J. A. Pask, "Reaction of Silicate Glasses and Mullite with Hydrogen Gas", J. Am. Cer. Soc., $68[8] 383-387(1982)$

5. S. T. Tso, "The Corrosion of Silicate Materials by Hydrogen Gas and Hydrofluoric Acid Solution", Ph.D. Thesis, University of California, Lawrence Berkley Laboratory, (1979) 
6. JCPDS International Center for Diffraction Data, Card 19-150, (1979).

7. C. Klein, and C. S. Hurlbut, Jr., Manual of Minerology, Twentieth Edition, 571, (1977).

8. C. A. Powell-Dogan et.al., "Residual Stress-Induced Grain Pullout in a 96\% Alumina", J. Am. Cer. Soc., 74 [3] $646-649(1991)$

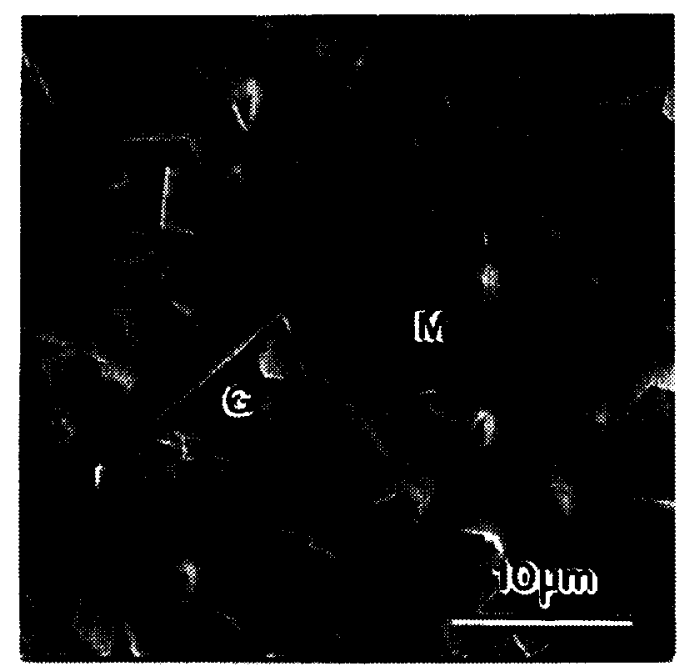

Figure 1.-Ceramograph of as-received mullite K-635, etched with 2:1 $\mathrm{HCl} / \mathrm{Hf:} \mathrm{H}_{2} \mathrm{O}$. 

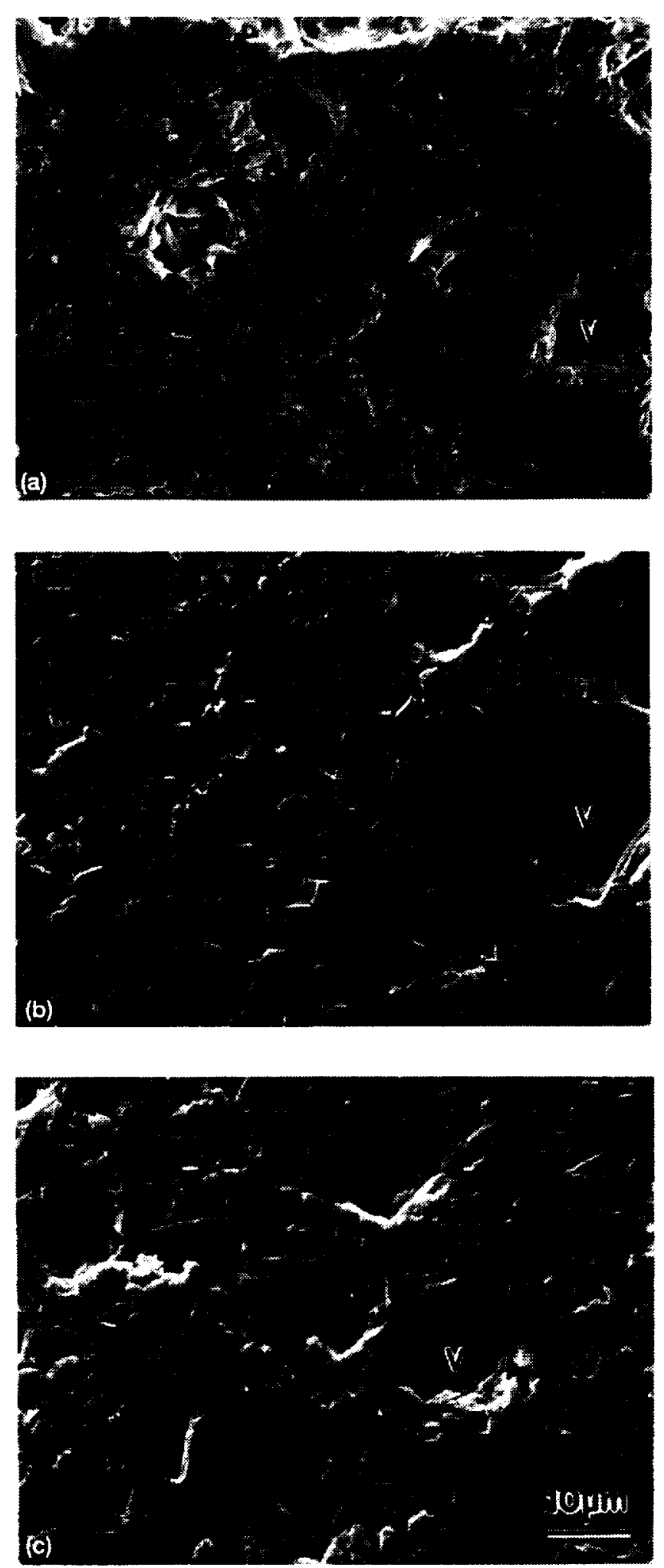

Figure 2.-SEM micrographs of mullite K-635 bar surfaces after exposure in hydrogen. (a) As-received. (b) $500 \mathrm{hr}$, $1050^{\circ} \mathrm{C}$. (c) $500 \mathrm{hr}, 1250^{\circ} \mathrm{C}$. 


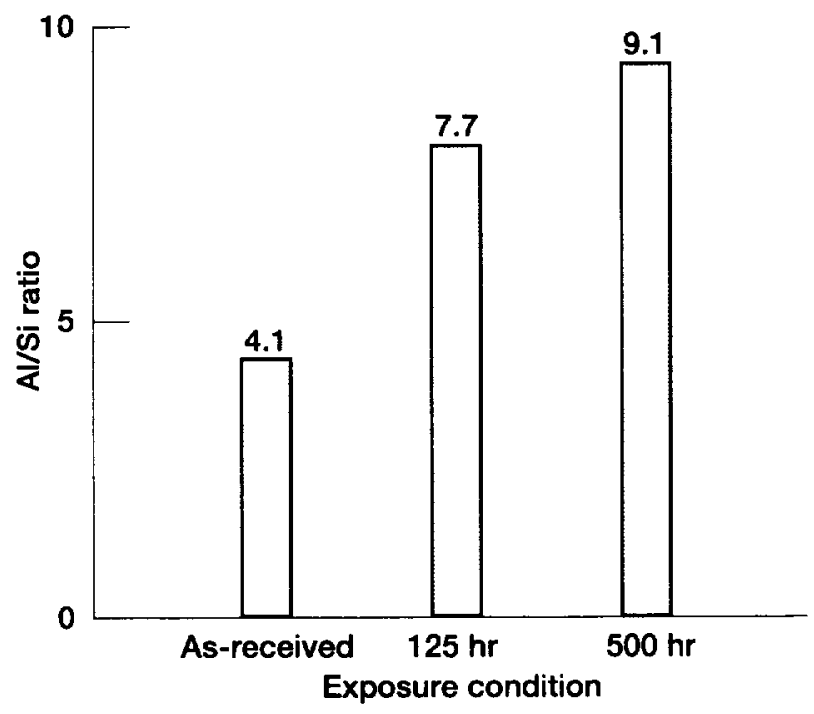

Figure 3.-Surface Al/Si ratios (XEDS) of mullite exposed to hydrogen at $1250^{\circ} \mathrm{C}$.

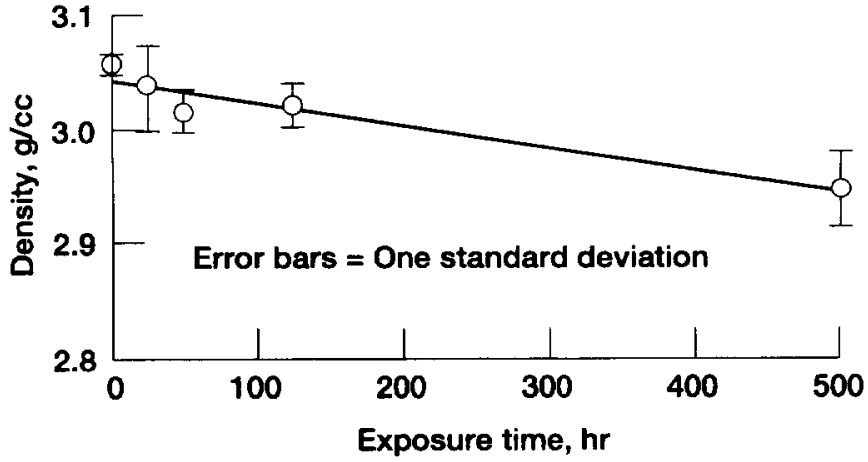

Figure 4.-Density of mullite K-635 as a function of hydrogen exposure at $1250^{\circ} \mathrm{C}$. 

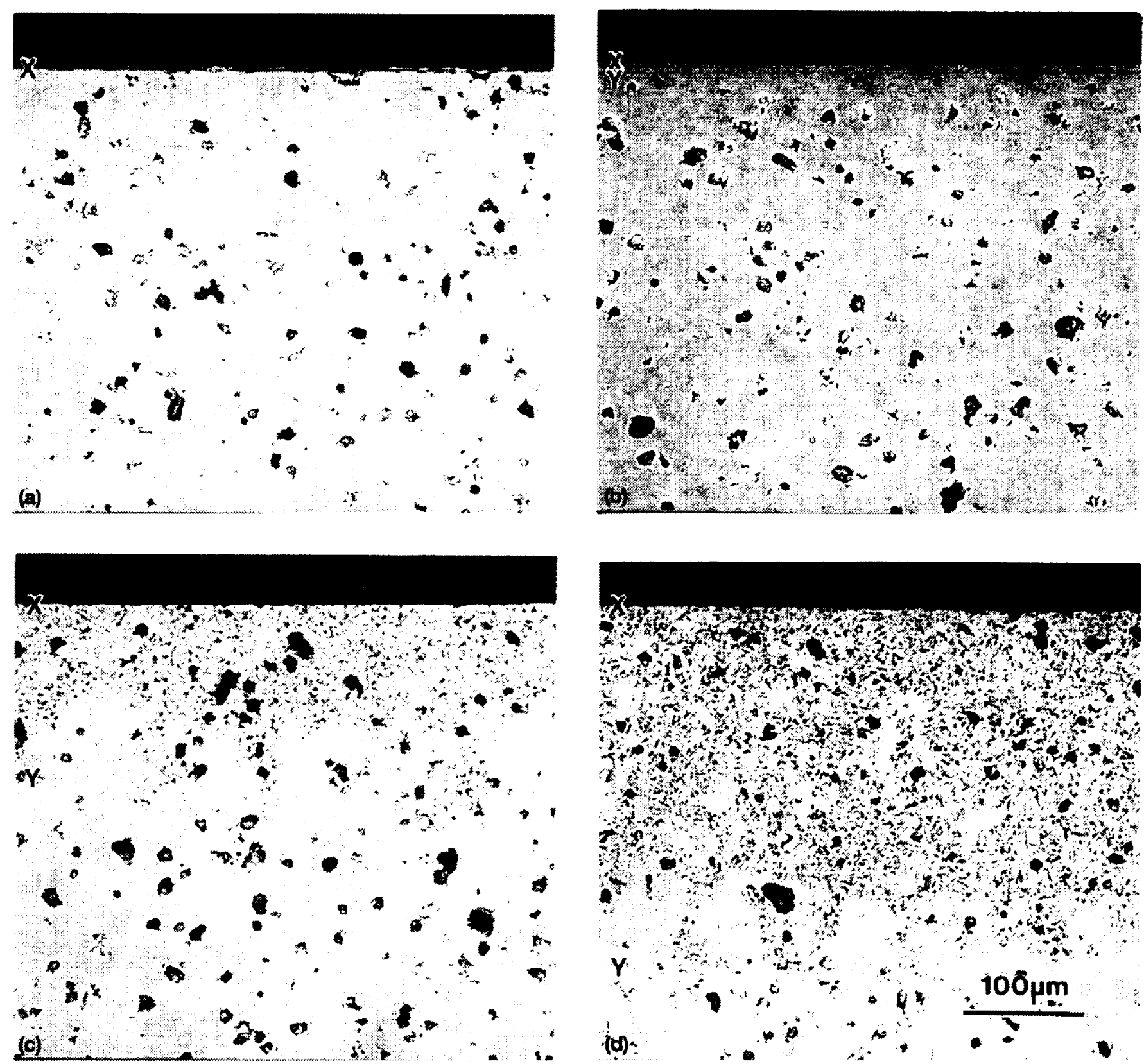

Figure 5.-BSE micrographs reveal porous reaction layer of mullite K-635 after hydrogen exposure. (a) As-received.

(b) $500 \mathrm{hr}, 1050^{\circ} \mathrm{C} ; \mathrm{Y}=4 \mu \mathrm{m}$. (c) $125 \mathrm{hr}, 1250^{\circ} \mathrm{C} ; \mathrm{Y}=150 \mu \mathrm{m}$. (d) $500 \mathrm{hr}, 1050^{\circ} \mathrm{C} ; \mathrm{Y}=300 \mu \mathrm{m}$. 


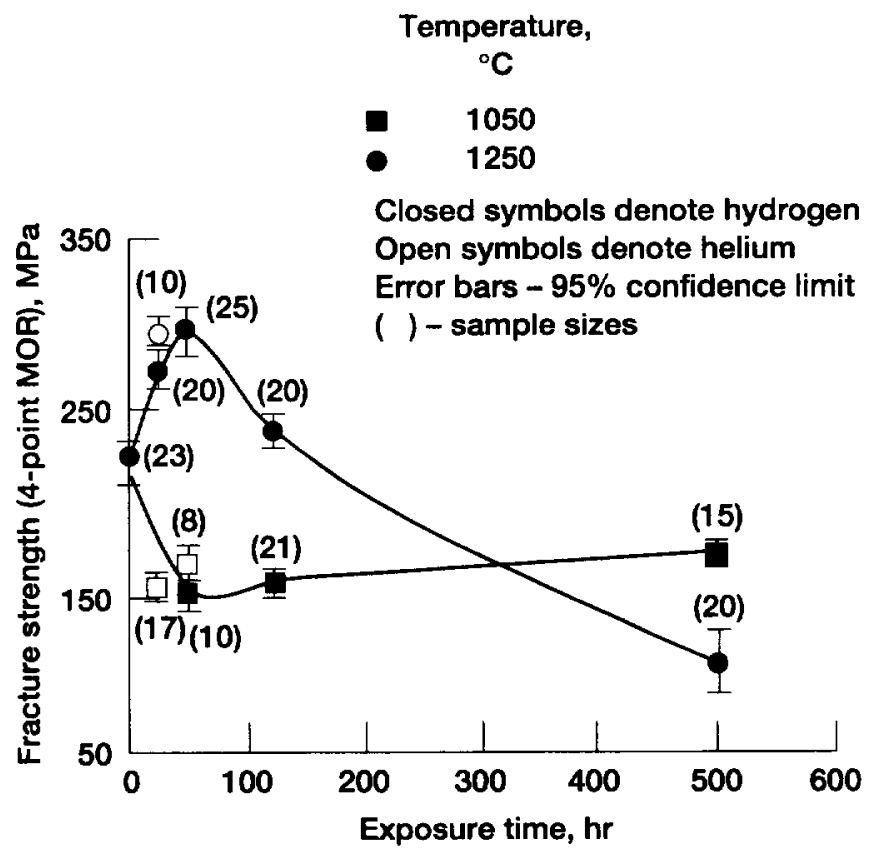

Figure 6.-Room temperature fracture strength of mullite $\mathrm{K}-635$ as a function of exposure time. 

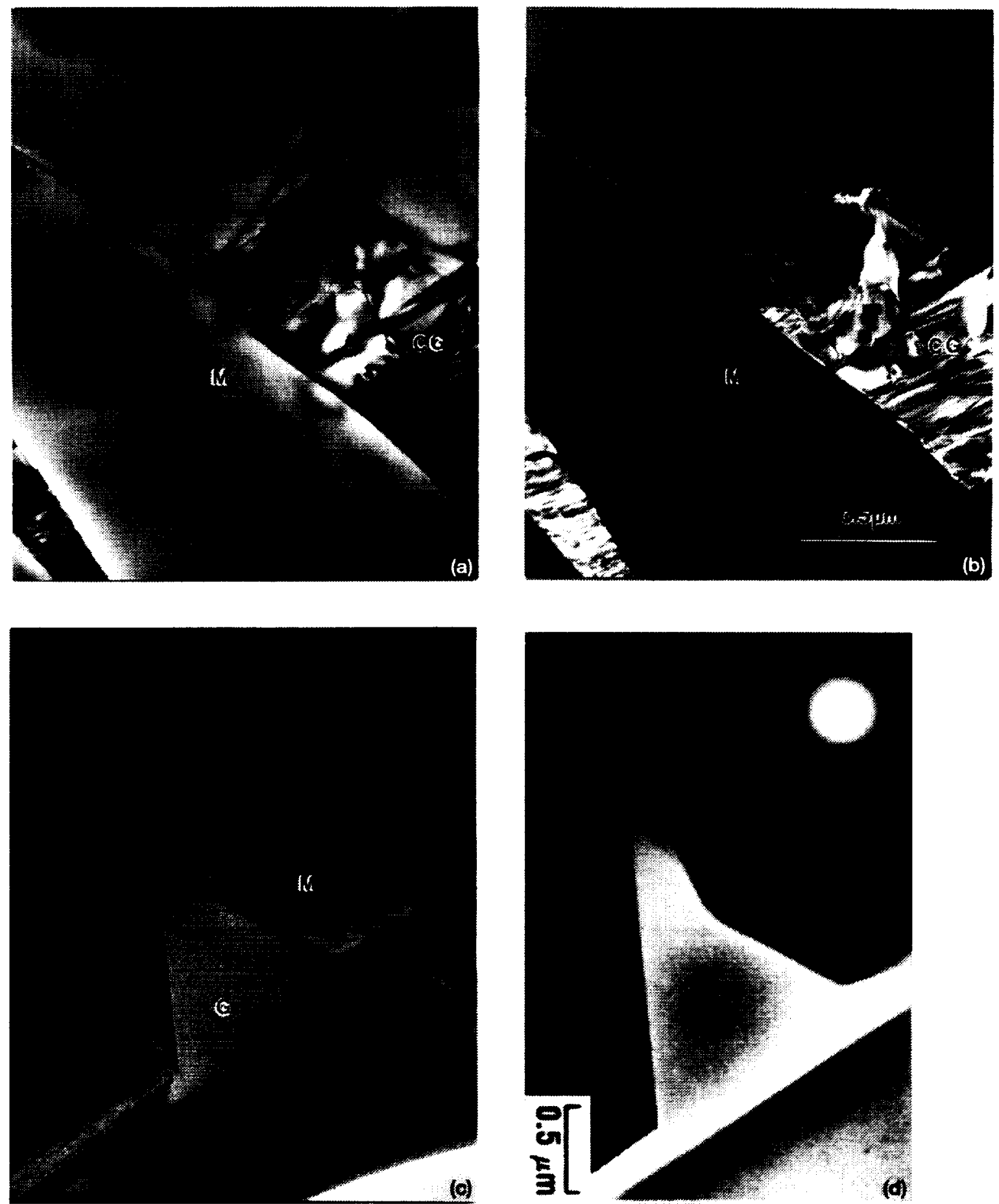

Figure 7.-TEM micrographs of grain-boundary phase in mullite $\mathrm{K}-635$ after hydrogen exposure. $M=$ mullite, $\mathrm{CG}=$ crystallized glass, $\mathrm{G}=$ glass. (a) $500 \mathrm{hr}, 1050^{\circ} \mathrm{C}$; bright field. (b) $500 \mathrm{hr}, 1050{ }^{\circ} \mathrm{C}$; dark field. (c) $500 \mathrm{hr}$, $1250{ }^{\circ} \mathrm{C}$; bright fieid. (d) $500 \mathrm{hr}, 1250^{\circ} \mathrm{C}$; dark field. 

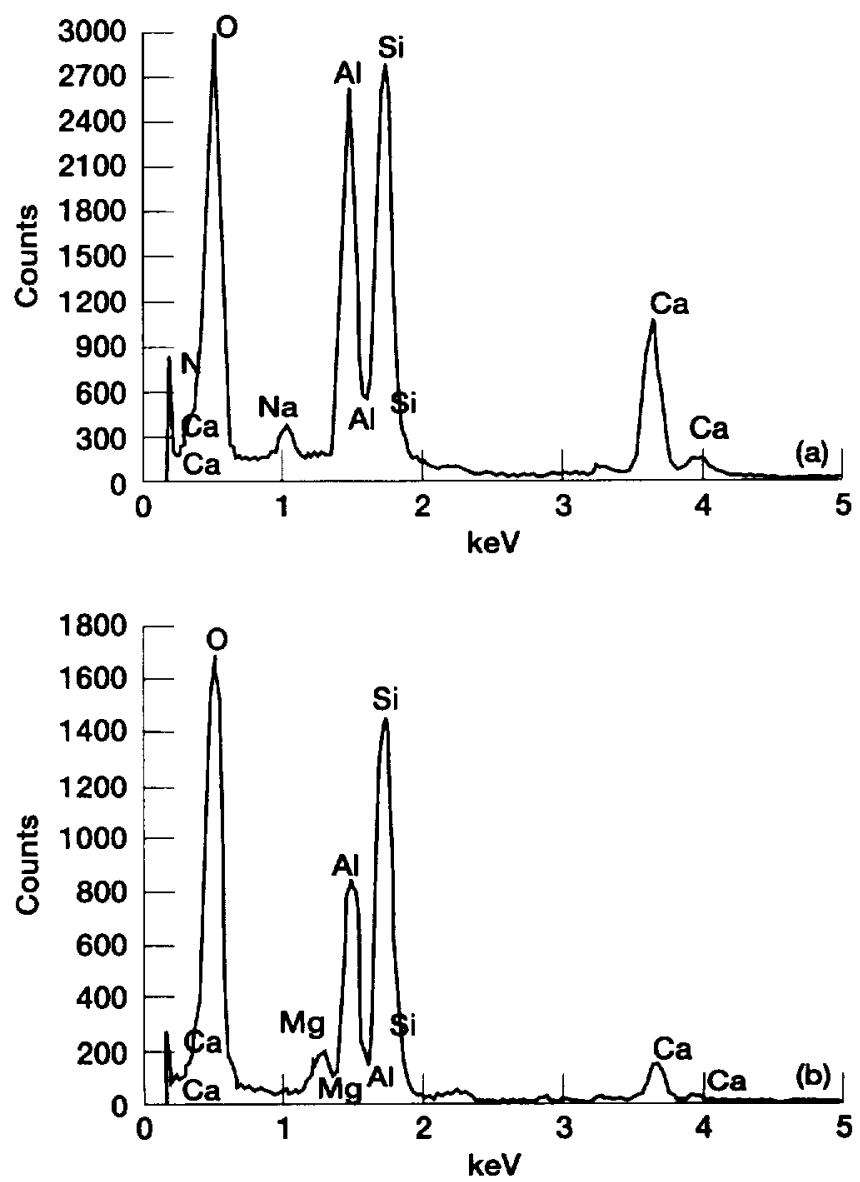

Figure 8.-XEDS of grain-boundary phase in mullite K-635 after hydrogen exposure. (a) $500 \mathrm{hr}, 1050^{\circ} \mathrm{C}$. (b) $500 \mathrm{hr}$, $1250^{\circ} \mathrm{C}$. 



(111)

- (10 $\overline{1})$

(012)

(000)

( $1 \overline{1} \overline{1} \overline{2}$

(101)

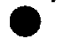

(a)
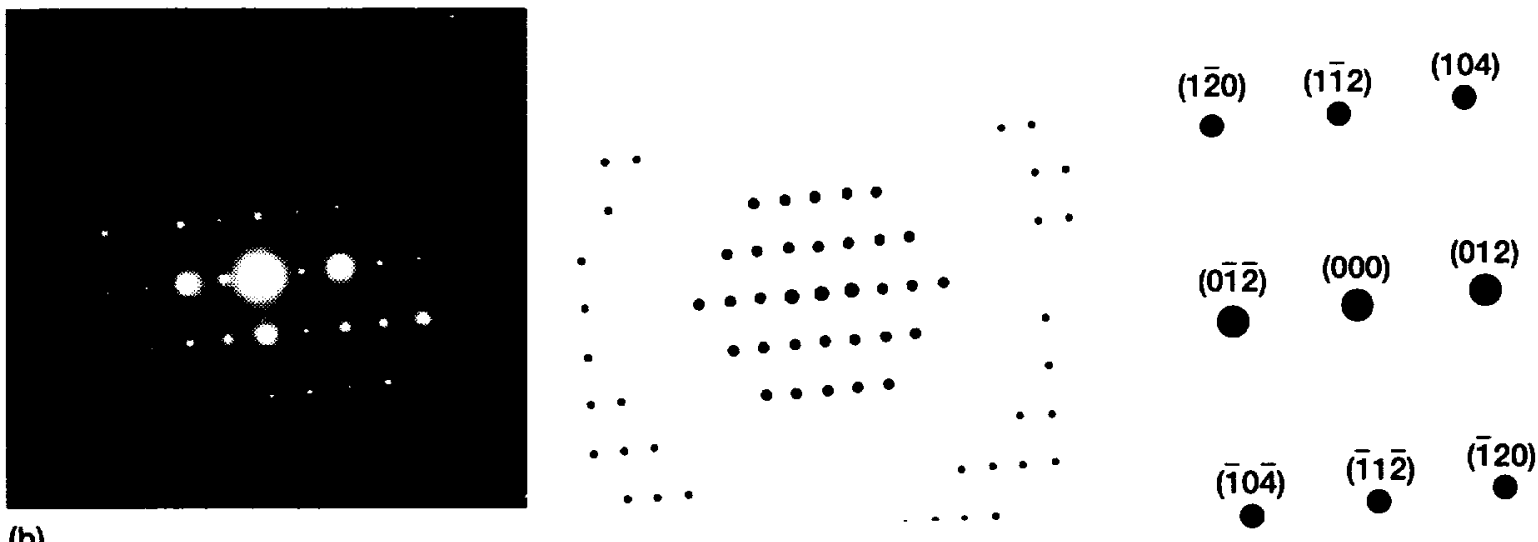

(b)
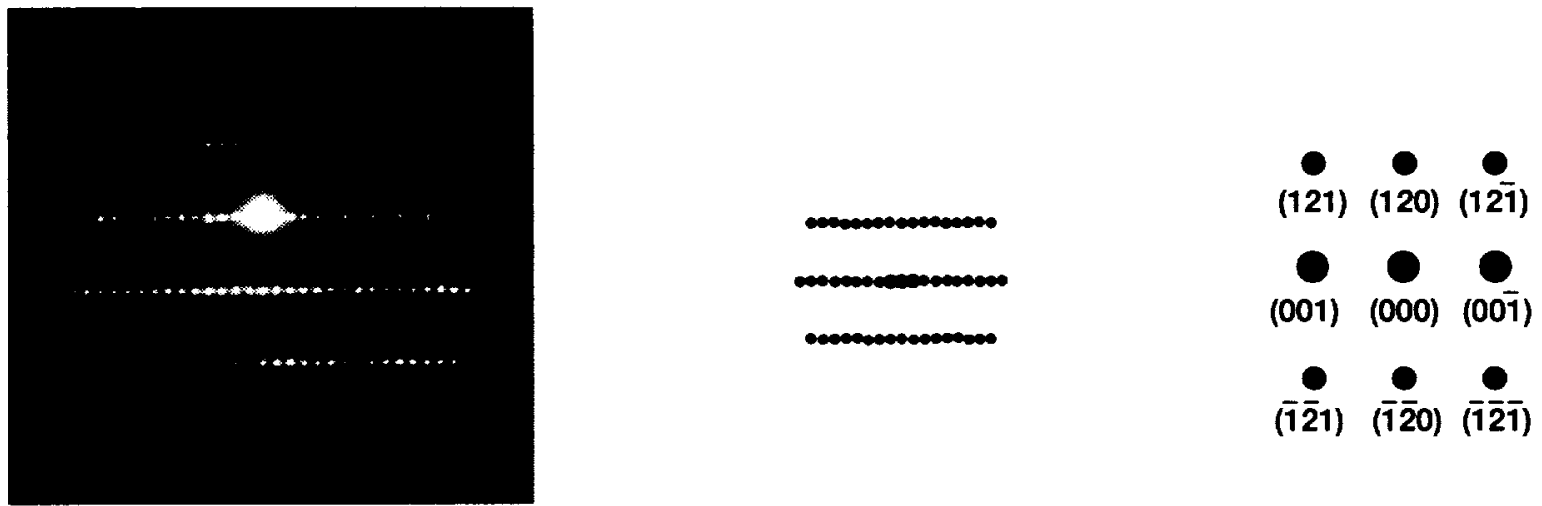

(c)

Figure 9.-Representative selected area diffraction patterns of crystalline phase formed in mullite K-635 at $1050^{\circ} \mathrm{C}$. Simulated zone axis patterns verify match with beidellite $\left[(\mathrm{Ca}, \mathrm{Na})_{2} \mathrm{Al}_{2} \mathrm{Si}_{4} \mathrm{O}_{10}(\mathrm{OH})_{2}\right] . \mathrm{H}_{2} \mathrm{O}$.







Figure 10.-TEM micrographs of mullite I after hydrogen exposure at $1050^{\circ} \mathrm{C}$. (a) Bright field. (b) Dark field.

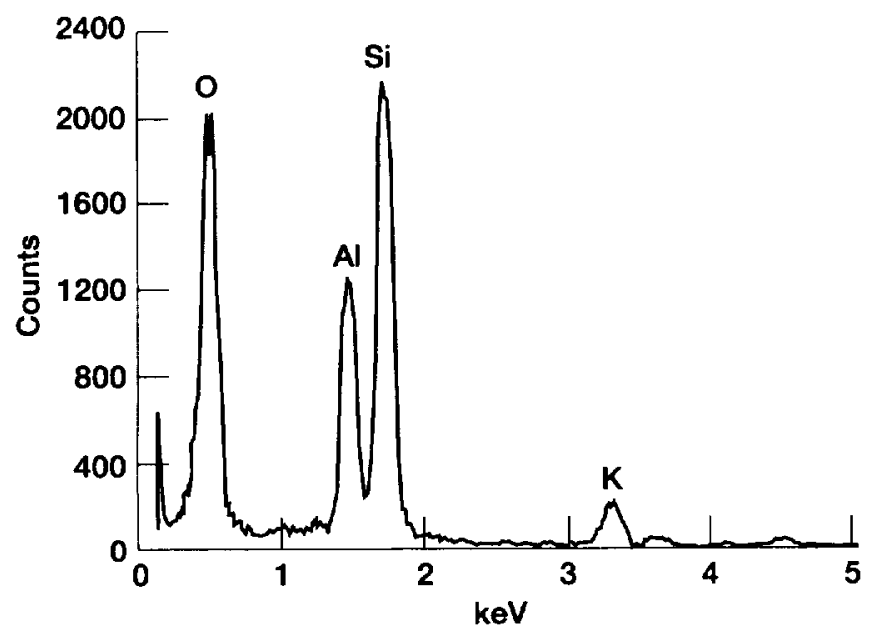

Figure 11.-XEDS of grain-boundary phase in mullite I after hydrogen exposure at $1050^{\circ} \mathrm{C}$. 
Public reporting burden for this collection of information is estimated to average 1 hour per response, including the time for reviewing instructions, searching existing data sources, gathering and maintaining the data needed, and completing and reviewing the collection of information. Send comments regarding this burden estimate or any other aspect of this collection of information, including suggestions for reducing this burden, to Washington Headquarters Services, Directorate for Information Operations and Repons, 1215 Jefferson Davis Highway, Suite 1204, Arlington, VA 22202-4302, and to the Office of Management and Budget, Paperwork Reduction Project (0704-018B), Washington, DC 20503.

\begin{tabular}{|l|l|l}
\hline 1. AGENCY USE ONLY (Leave blank) & $\begin{array}{c}\text { 2. REPORT DATE } \\
\text { June } 1996\end{array}$ & $\begin{array}{r}\text { 3. REPORT TYPE AND DATES COVERED } \\
\text { Technical Memorandum }\end{array}$
\end{tabular}

\section{TITLE AND SUBTITLE}

Hot Hydrogen Exposure Degradation of the Strength of Mullite

5. FUNDING NUMBERS

Thomas P. Herbell, David R. Hull, and Anita Garg

WU-242-20-06

7. PERFORMING ORgaNIZATION NAME(S) AND ADDRESS(ES)

8. PERForming ORGANIZATION REPORT NUMBER

National Aeronautics and Space Administration

Lewis Research Center

Cleveland, Ohio 44135-3191

E-10091

9. SPONSORINGMONITORING AGENCY NAME(S) AND ADDRESS(ES)

10. SPONSORINGMONTOORING AGENCY REPORT NUMBER

National Aeronautics and Space Administration

Washington, D.C. 20546-0001

NASA TM-107153

11. SUPPLEMENTARY NOTES

Thomas P. Herbell and Anita Garg, NASA Lewis Research Center; David R. Hull, National Research Council-NASA

Research Associate at Lewis Research Center. Responsible person, Thomas P. Herbell, organization code 5130, (216) 433-3246.

12a. DISTRIBUTION/AVAILABILITY STATEMENT 12b. DISTRIBUTION CODE

Unclassified - Unlimited

Subject Category 27

This publication is available from the NASA Center for Aerospace Information, (301) 621 -0390 .

13. ABSTRACT (Maximum 200 words)

This study deals with the corrosion of near stoichiometric mullite $\left(3 \mathrm{Al}_{2} \mathrm{O}_{3}-2 \mathrm{SiO}_{2}\right)$ by pure dry hydrogen gas. Exposure of the mullite samples was at temperatures of 1050 and $1250^{\circ} \mathrm{C}$ for times up to 500 hours. Preferential attack of the aluminosilicate glass present in the grain boundaries of the mullite occurred after 125 hours at $1250^{\circ} \mathrm{C}$. Hydrogen scrubbing of the $\mathrm{SiO}_{2}$ from the glassy grain boundaries and the mullite grains yielded a porous alumina-rich surface. The room temperature strength increased after short exposure times at $1250^{\circ} \mathrm{C}$ (up to 125 hours), then decreased by 53 percent after exposure for 500 hours. At $1050^{\circ} \mathrm{C}$, all exposure times ( 25 to 500 hours) decreased the strength. After 500 hours in hydrogen at $1050^{\circ} \mathrm{C}$, the room temperature strength of mullite decreased 22 percent. We also observed a rapid 25 percent strength loss after short exposure times at $1050^{\circ} \mathrm{C}$. This is attributed to the calcium/hydrogen assisted crystallization of the glassy, grain-boundary phase.



15. NUMBER OF PAGES

16. PRICE COOE

$\mathrm{A} 03$

20. LIMITATION OF ABSTRACT 


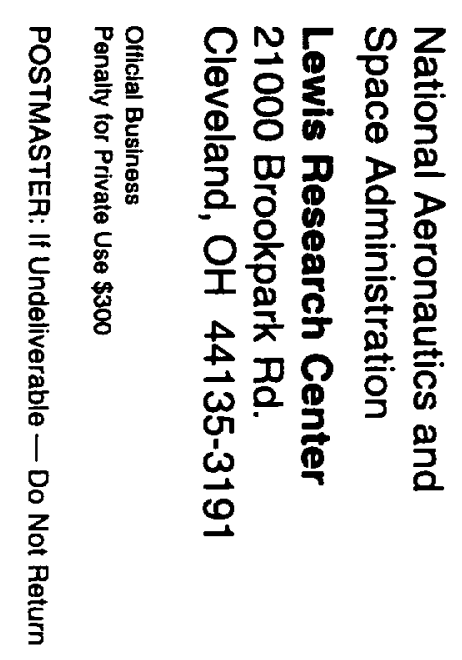

